\title{
Development Strategy of Earthenware Craft Business Group with Analytic Network Process Approach
}

\author{
Khafid Ismail $^{1}$, Sucihatiningsih Dian Wisika Prajanti ${ }^{* *}$, Widiyanto ${ }^{3}$ \\ ${ }^{1}$ Department of Economic Education, STKIP Nurul Huda Sukaraja, Indonesia \\ ${ }^{2}$ Department of Economic Development, Universitas Negeri Semarang, Indonesia \\ ${ }^{3}$ Department of Economic Education, Universitas Negeri Semarang, Indonesia \\ ${ }^{1}$ khafidismail@gmail.com, 2dianwisika@yahoo.com, ${ }^{3}$ wied@mail.unnes.ac.id, *corresponding author
}

\begin{abstract}
This study aims to develop a strategy for developing Earthenware Craft Business Group in Kasongan Tourism Village. This research method uses mix methods, used namely primary and secondary data. The analytical method used is the Analytic Network Process (ANP) analysis. The results showed that the priority order of the first criteria was the aspect of sales with a value weight of $49.3 \% \%$, followed by the business actor aspect with a value weight of $31 \%$, and the aspects of business products with a value weight of $19.5 \%$. The finding of this research is that the sales aspect is a priority aspect to be developed. From the final results the determination of priorities obtained three main priorities namely aspects of product innovation with a weight of $39.16 \%$, partnership with a weight of $38.81 \%$ and training with a weight of $36.32 \%$.
\end{abstract}

Keywords: earthenware, business, kasongan, analytic network process

\section{Strategi Pengembangan Kelompok Usaha Kerajinan Gerabah dengan Pendekatan Analytic Network Process}

\begin{abstract}
Abstrak
Penelitian ini bertujuan untuk menyusun strategi pengembangan kelompok usaha kerajinan gerabah di Desa Wisata Kasongan. Metode penelitian ini menggunakan pendekatan kualitatif dan kuantitatif. Jenis data yang digunakan ada dua yaitu data primer dan sekunder. Metode analisis yang digunakan adalah analisis Analytic Network Process (ANP). Hasil penelitian menunjukkan bahwa urutan prioritas dari kriteria tersebut yang pertama adalah aspek penjualan dengan bobot nilai sebesar $49,3 \% \%$, selanjutnya diikuti oleh aspek pelaku usaha dengan bobot nilai sebesar 31 $\%$, dan aspek produk usaha dengan bobot nilai sebesar 19,5\%. Temuan dari penelitian ini adalah aspek penjualan adalah aspek yang diprioritaskan untuk dikembangkan. Dari hasil akhir penentuan prioritas diperoleh tiga prioritas utama yaitu aspek inovasi produk dengan bobot $39,16 \%$, kemitraan dengan bobot $38,81 \%$ dan pelatihan dengan bobot $36,32 \%$.
\end{abstract}

Kata kunci: gerabah, kasongan, kerajinan, pengembangan

\section{INTRODUCTION}

Indonesia is a developing country which its economy is largely supported by the industrial sector and Micro, Small and Medium Enterprises (MSMEs). The existence of MSMEs in Indonesia has a great influence on the national economy. In addition to contributing to the formation of Gross Domestic Product (GDP), MSMEs in Indonesia also play a major role in absorbing labor so as to reduce unemployment. Therefore, the existence of this business needs to be maintained and continues to be developed in order to give greater contribution to the national economy. One of the MSMEs that contributes to the community's economy is the earthenware craft business located in Kasongan Tourism Village, Bantul, Yogyakarta. According to the Big Indonesian Dictionary (KBBI) 
earthenware is kitchen utensils (for cooking utensils and so on) made from clay and then burned. The earthenware produced in Kasongan currently does not only consist of household utensils, but also there have been many that produce earthenware as decoration, flower vases, jars and others or commonly called ceramic handicrafts.

Bantul Regency is one of the regencies located in DIY Province that has tourism potential both in natural and cultural tourism. Kasongan Village is one of the tourism villages that has its own uniqueness because in this village most of the residents earn a living as earthenware artisans. Earthenware craft business has been much wrestled by people in the surrounding considering the enthusiasts of this product are not only from local residents but also in demand by foreign tourists. As a tourism village, Kasongan has its own advantages because with the large number of tourists visiting, it certainly provides a broad market share for the surrounding earthenware artisans. Promising potential earthenware does not necessarily provide welfare for the surrounding community, considering that currently the earthenware business in Kasongan has not progressed as before. The reduced existence of the earthenware business is caused by several factors, both internal and external factors.

Earthenware production activities in Kasongan are still classified as traditional because the production equipments used have not been touched by modern technology. According to research by Ueda et.al (2017) it is stated that the majority of earthenware artisans, especially in the Southeast Asia, tend to survive using traditional production tools because they are already accustomed to and are a hereditary cultural heritage to be carried out. This makes the competitiveness of the earthenware produced also still low and inferior to products from other regions. The large number of earthenware craftsmen in Kasongan makes business competition tighter. Most entrepreneurs feel that their main rivals are big entrepreneurs. This is because, capital, technology, labor and the skills they have are not the same as big entrepreneurs. Besides this, the business orientation of small entrepreneurs is still as a supplier for large entrepreneurs, while large entrepreneurs are exporters.

In general, business competition is a feud or rivalry between business people who are independently trying to get consumers by offering good prices with good quality goods or services too (Mujahidin (2007). Meanwhile, according to Kuncoro (2007), competition is the time when an organization or individual competes to achieve the desired goals such as consumers, market share, survey ratings, or needed resources. The existence of intense competition in the earthenware business makes the earthenware business, especially businesses that are still on a small scale, difficult to develop (Irdayanti, 2012).

Another problem faced by earthenware entrepreneurs in Kasongan is limited business capital (Fatimah, 2012). Because of this limited capital, the entrepreneurs find it difficult to develop earthenware production and marketing. According to Nugraha (2011) business capital is money used as a main part (parent) for trading, releasing money, and so on; property (money, goods, etc.) that can be used to produce something that adds to wealth. The problem here is not whether capital is important or not, because its existence is really needed, but how to manage capital optimally so that the business can run 
smoothly (Amirullah, 2005). In addition to limited capital, some entrepreneurs have experienced difficulties in obtaining raw materials. Raw materials are inventories purchased by companies to be processed into semi-finished goods and finally finished goods or final products from the company (Syamsuddin, 2001). Meanwhile, according to Hanggana (2006) what is meant by raw material is something used to make finished goods; the materials must stick together with finished goods.

In a company, raw materials and auxiliary materials have a very important meaning, because they are the capital of the production process until the production results. All companies that produce to generate one or several kinds of products will always need raw materials for the implementation of the production process. Raw materials for making earthenware must be truly high qualified because it will directly affect on the quality of the earthenware produced. The price of raw materials which are expensive and difficult to be obtained sometimes hinders the production of earthenware in Kasongan (Hastuti, 2010). Although Kasongan is actually a tourism village that is crowded with tourists, but this condition does not necessarily make earthenware marketing develop.

. Kotler (2005) explains that what is meant by marketing is a social and managerial process where individuals and groups get their needs and desires by creating, offering, and exchanging products that are valuable to each other. According to Boyd (2000), marketing is a social process that involves important activities that enable individuals and companies to get what they need and want through exchanges with others and to develop exchange relationships. The majority of earthenware entrepreneurs in Kasongan still rely on marketing by ordering. This marketing method will certainly provide limitation for earthenware production because they will only produce if there is an order. Although there are those who market directly to the market or displayed in galleries, these methods are also not very promising.

The majority of earthenware artisans in Kasongan are artisans who come from Brebes who migrate to Kasongan to become earthenware workers. However, recently, many of these craftsmen have returned to the village or changed professions because their profession as earthenware craftsmen is still not enough to meet their daily needs. As a result, earthenware artisans with qualified skills remaining are only a few. There are also many young people in Kasongan who are reluctant to become business artisans, bearing in mind that this business is less promising. The increasingly limited quality of human resources makes the earthenware craft business in Kasongan increasingly declines.

The local government actually has been trying to develop the earthenware craft business in Kasongan by issuing several regulations such as establishing the UPT of Kasongan ceramic assistance, and providing production equipment, training and assistance. Still, some of these efforts are also not optimal because it is not fully able to advance the earthenware business in Kasongan. The existence of various highly complex problems faced by the earthenware artisans makes it difficult to develop the earthenware business in Kasongan. Therefore, this study aims to formulate a strategy for developing the business group of earthenware craft in Kasongan Tourism Village. 


\section{METHODS}

This research was a research with qualitative and quantitative approaches. The use of these methods based on several things which were as a research method, mix methods focus on collecting, analyzing, and mixing quantitative and qualitative data in a single or advanced research (Sugiyono, 2017). The data used in this study are two types, namely primary data and secondary data. Primary data in this study were sourced from observation, interviews, documentation, and questionnaires. Meanwhile, secondary data were sourced from literature studies from journals, books, articles, and publications from government agencies. This study used a purposive sampling technique in determining the samples in this study. This technique has a meaning that is by choosing research subjects and research locations with the aim to study or understand the main problems to be studied (Herdiansyah, 2009). The sample of key person in this study consisted of the Office of Cooperatives, Micro Small Business and Industry of Bantul Regency, Development Planning Agency at Sub-National Level of Bantul, Chair of the Joint Business Cooperative of Kasongan Earthenware Craftsmen and UPT of Kasongan Ceramics Companion.

This study used the Analytic Network Process (ANP) method which is a development of the Analytical Hierarchy Process (AHP) method. ANP allows interaction and feedback from elements in the cluster (inner dependence) and between clusters (outer dependence). ANP is applied to decision-making that is complicated, complex and requires a variety of interactions and dependencies. As a development method of AHP method, ANP still uses Pairwise Comparison Judgment Matrices (PCJM) method between similar elements. ANP pairwise comparisons are conducted between elements in a component or cluster for each interaction in the network (Rusydiana, 2013).

Analytic Network Process (ANP) is also a mathematical theory that is able to analyze the influence of the assumptions approach to solve the form of problems. ANP depends on the existing alternatives and criteria. Saaty (in Rusydiana, 2013) explains the technical analysis of ANP using pairwise comparisons on project alternatives and criteria. In ANP networks, levels in AHP are called clusters that can have criteria and alternatives in them.

\section{RESULTS AND DISCUSSIONS}

This study tries to formulate a strategy for developing business group of earthenware craft in Kasongan Tourism Village. The strategy in this study is formulated using the Analytic Network Process (ANP) method. This method is often used by many researchers because the calculation process using the ANP method is considered more complex than the AHP method. The calculation process by using the ANP method to the supermatrix calculation process consists of unweighted matrices, weighted matrices, and limit matrices. While the AHP calculation is only up to the calculation process of the consistency ratio (CR). ANP is a mathematical theory that is able to analyze the influence through the assumptions approach to solve a problem. If in AHP, there will be levels of objectives, criteria, subcriteria and alternatives. 
In the Analytic Network Process (ANP) there will be criteria, nodes and alternatives obtained from the results of field surveys, previous research and discussed with experts in their fields (key person). From the results of surveys and discussions with key people, several criteria and alternatives obtained, including aspects of business actors, aspects of business products and aspects of sales. Meanwhile, the alternatives consist of Human Resources (HR), Product Quality and Marketing. Based on several criteria and alternatives that have been obtained, it can be arranged a model for the development of earthenware craft business groups in Kasongan Village. In ANP analysis, it is known that the term of inner dependence is that a node in a cluster can affect other nodes in the same cluster. Meanwhile, the term of outer dependence where nodes on different criteria can influence each other.

ANP also aims to find out the overall effect of all elements exist. Therefore, all nodes must be arranged and prioritized in a network hierarchy framework, and a comparison is made to obtain priority order from a set of nodes. The results of the influences on each criterion will be weighted with the importance level of each node added to obtain the overall effect of each node or criterion. The process for analyzing a decision requires the existence of criteria, before deciding from the various alternatives that exist. The existence of criteria aims to describe the definition of the problem in a concrete form and is considered as a target to be achieved. The analysis of the assessment criteria is intended to obtain a measurement standard. Henceforth, it will be made as a tool in comparing various alternatives. The following is the model picture for developing the business group of earthenware craft in Kasongan Village:

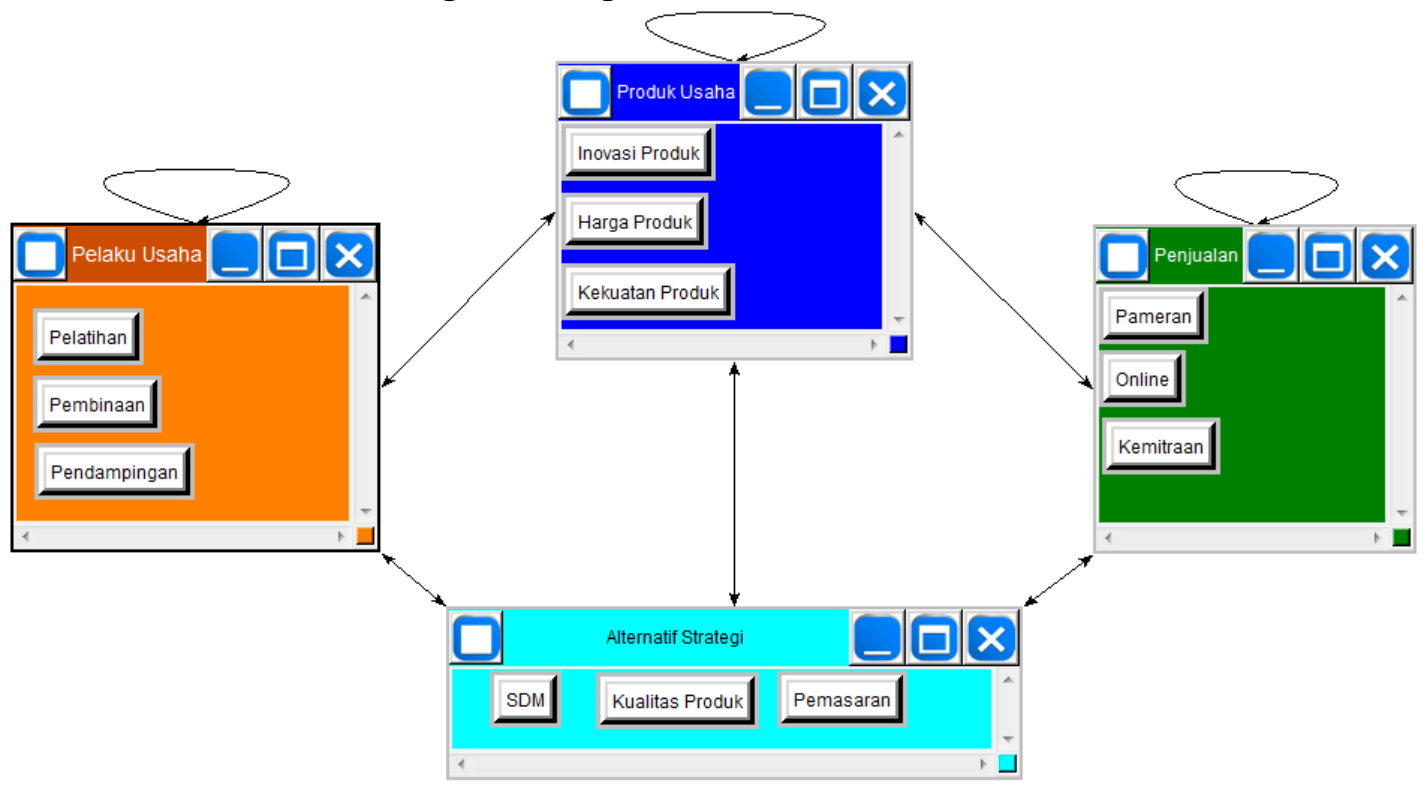

Figure 1. ANP Framework Model of the Development Strategy of the Earthenware Craft Business Group in Kasongan Village

Figure 1 shows that ANP analysis used in this study uses three criteria in the effort to develop the earthenware craft business group in Kasongan Village. The three criteria include business people, business products, and sales. Whereas for the alternative 
strategies are HR, product quality and marketing. The arrow in the picture above shows that there is feedback from the relationship between clusters / criteria. Meanwhile, for a circle is a loop, which shows that there is a relationship between nodes in a cluster / criteria. This is called an inner dependence relationship. In addition, there is a direct relationship between several clusters such as clusters of business people aspect, business products and sales.

\section{Pairwise Comparison Matrix between Nodes (Inner Dependence)}

Paired comparison matrices of inner dependence are obtained from the relationships between nodes contained in the clusters. The relationship between nodes in a cluster will form a curved line above the criteria or called a loop as can be seen in Figure 1. Inner dependence relationship can occur among others: aspect of business people obtained by pairwise comparisons between training, coaching, and assistance. Then aspects of business products include product innovation, product price and product strength. Meanwhile, the aspects of sales include exhibition, online and partnership. Curved lines or loops appear on interconnected nodes on the same criteria / cluster. The loop line appears in all aspects of the criteria.

Business people are one of the most important aspects of the sustainability of the earthenware craft business in Kasongan Tourism Village. In the effort to develop the earthenware craft business, there are three sub-criteria to be considered, including training, coaching, and assistance. Of the three sub-criteria are then used as a questionnaire in order to obtain the value which is then processed with Super Decision software with the following results:

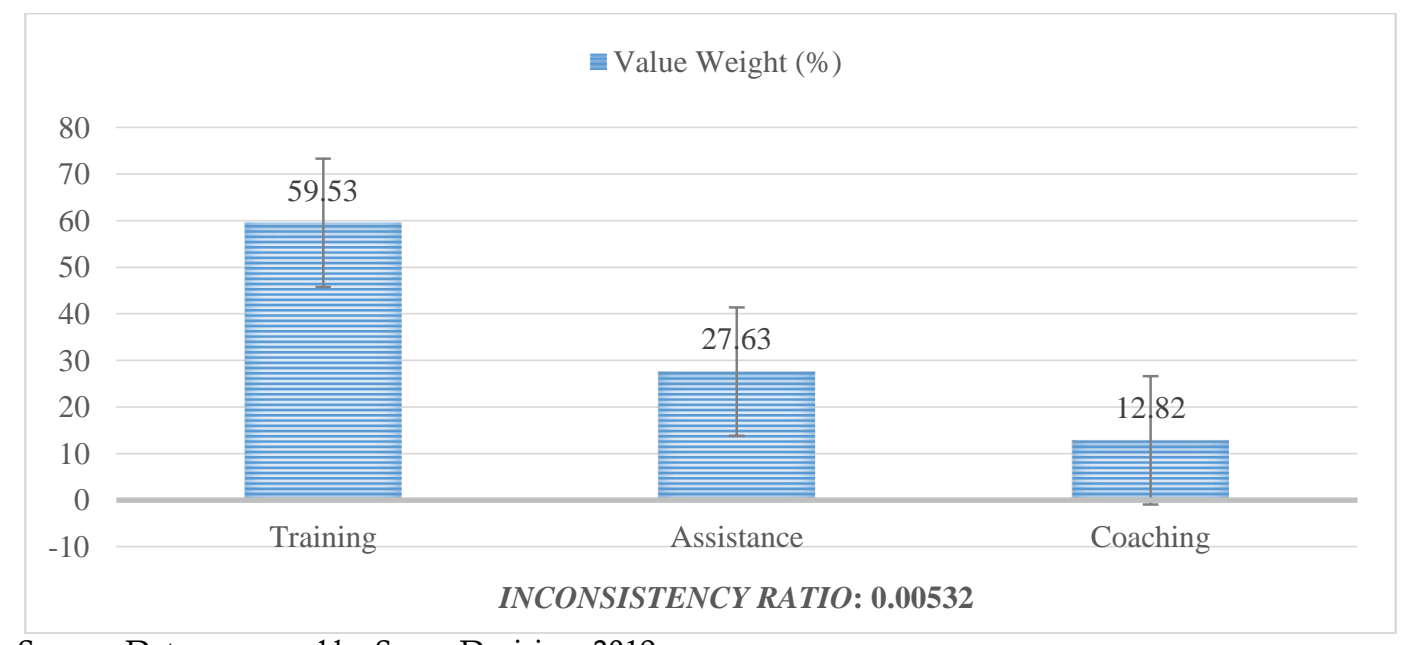

Source: Data processed by Super Decision, 2019.

Figure 2. ANP Output of Business People Criteria

Based on Figure 2, it can be seen that the effort to develop the earthenware craft business groups in Kasongan Tourism Village in the aspect of business people in the order of the first sub-criteria is training with a weight of $59.53 \%$. Next, in the second order is assistance with a value weight of $27.63 \%$ and in the third order is coaching with a value 
weight of $12.82 \%$. The value of the inconsistency ratio in the aspect of product quality is $0.00532<0.1$, which means the results of the analysis can be accepted.

From the results of this analysis, it can be known that training is an important thing in developing the skills and expertise of the earthenware craft business people in Kasongan. The training will be able to improve the skills and expertise of earthenware craft business people so as to increase productivity and be able to develop the business they run. The training that can be given can be in the form of product innovation training, business management training and training in marketing products.

Besides training, there is also assistance that ranks second priority. Assistance is an effort that can be done by the local government to the earthenware craft business people in order to develop the business they run. This assistance can be in the form of assistance from production to marketing which can be done regularly or periodically. With this assistance, it is expected that business people who have not been able to develop their businesses and have business problems can be resolved in the right way through the assistance process.

The sales aspect is also one of the aspects that becomes the concern for the development of the earthenware craft business group in Kasongan. In an effort to develop the earthenware craft business, there are three sub-criteria that are considered in the aspect of sales, including: partnership, online and exhibition. The results of data processing from the aspect of sales can be seen in the following figure:

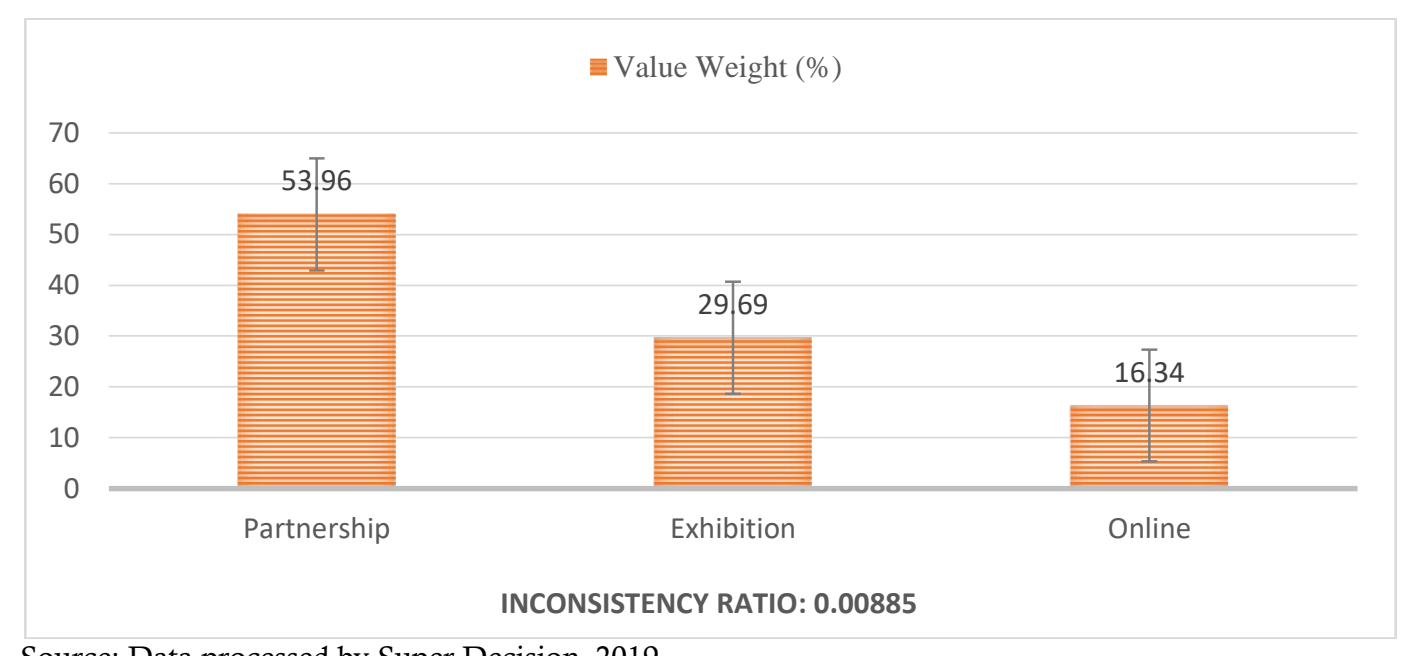

Source: Data processed by Super Decision, 2019.

Figure 3. ANP Output of Sales Criteria

Based on Figure 3, it can be seen that in the aspect of sales, the sub-criteria that rank first is partnership with a value weight of $53.96 \%$. Then followed by the sub-criteria in the second order, namely exhibition with a value weight of $29.69 \%$ and the third order is online with a value weight of $16.34 \%$. Partnership is an important element in developing Kasongan earthenware business. This business partnership can be done with the government, the private sector, or even with other businesses so that the earthenware craft entrepreneurs will not experience difficulty in marketing their products because there is a 
market guarantee from their business partners. Then the second sub-criteria is exhibition. Exhibition is a direct marketing tool that can be utilized by Kasongan earthenware business people to market their products directly to consumers. By participating in exhibitions, especially exhibitions in various regions, they will be able to reach a wider market share.

Earthenware marketing can also be done online to reach a wider market. Khotimah et al (2012) in their research said that despite advances in technology and information in the form of internet, it could be an alternative solution for earthenware artisans to market their products online so that they could reach a wider market. With this wider market area, it will have a positive impact on the earthenware business because certainly the artisans can increase their production capacity and increase their income (Niziolek, 2013).

The next aspect that is no less important is the aspect of business products. In an effort to develop earthenware craft business, there are three sub-criteria that are considered in the aspect of business products, including: product innovation, product price, and product strength. The result of data processing from the aspect of business products can be seen in the following figure:

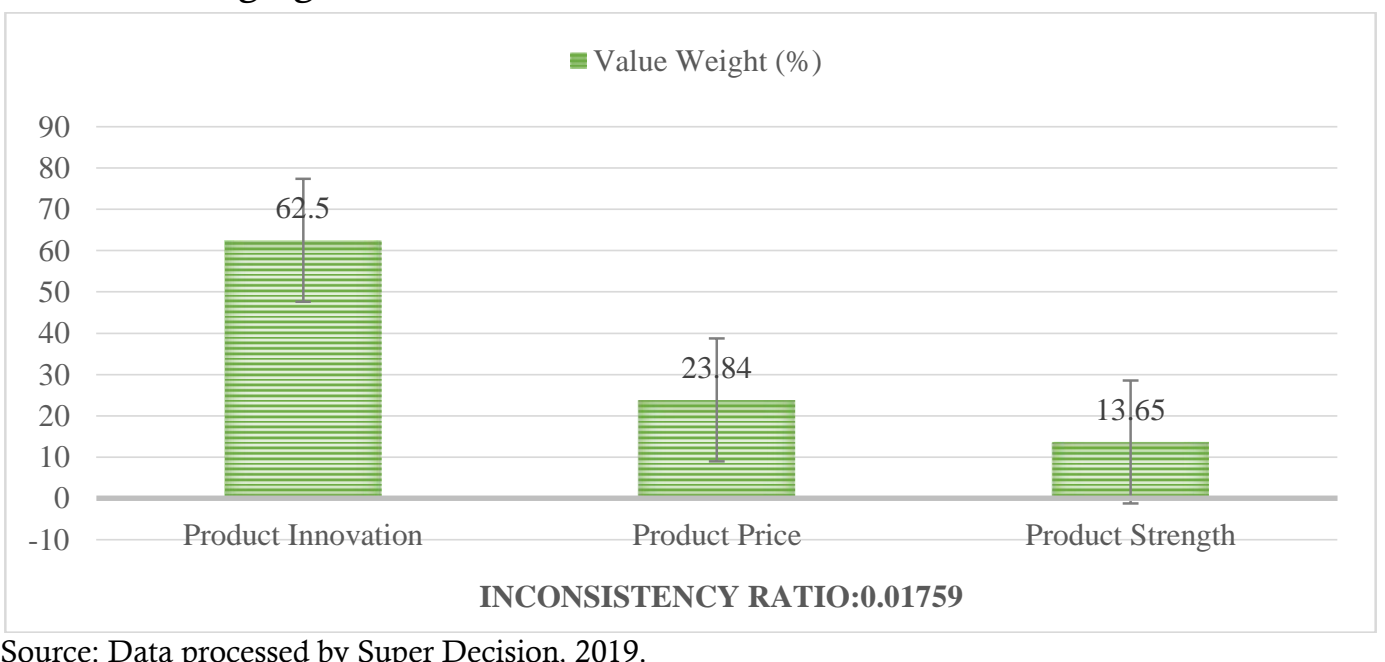

Source: Data processed by Super Decision, 2019.

Figure 4. ANP Output of Business Product Criteria

Based on Figure 4, it can be seen that the effort to develop the earthenware craft business group in Kasongan Tourism Village in the aspect of business products in the order of the first sub-criteria is product innovation with a value weight of $62.50 \%$. Next, in the second order is product price with a value weight of $23.84 \%$ and in the third order is product strength with a value weight of $13.65 \%$. The value of the inconsistency ratio in the aspect of product quality is $0.01759<0.1$, which means that the results of the analysis can be accepted. Based on these results, this shows that product innovation is a very important element in the development of the earthenware craft business. In a study conducted by Sofa (2011), it is stated that earthenware innovation in this era is very much needed, considering the emergence of various innovative earthenware substitute products that threaten the existence of earthenware produced by local communities. According to Henden et al. (2012) innovation in the design of earthenware craft needs to be done because the desires and interests of consumers can change at any time in accordance with 
the times. Earthenware is a craft product that has art and beauty that become the selling value of the product. The higher the value of art and its beauty, the more it will attract consumers.

The value of art and the form of earthenware tend to change along with the times because it follows the demands from the market. Therefore, product innovation is very important in order to the earthenware products produced are not backward and can be sold in the market. In addition to product innovation, the product price element is also important. In accordance with the law of demand that the lower the price of a product, the higher the demand for that product. Therefore, the business people must be careful in determining prices so that earthenware products remain in demand in the market and continue to provide benefits.

\section{Pairwise Comparative Matrices between Groups / Criteria}

In the ANP method, in addition to comparisons between groups in one cluster can also be made comparisons between groups of clusters. The pairwise comparison matrix between criteria / groups is made based on the questionnaires that have been filled out by key person. This pairwise comparison matrix uses values with numbers 1-9. Then, after the assessment done, it will be continued with the calculation of the mean value of the questionnaires that have been filled, so that it will be obtained a relative value. The relative value will then be used as an input value on ANP, which is super decision application made by $\mathrm{M}$ Saaty. The following are the results of the comparison of groups /between criteria:

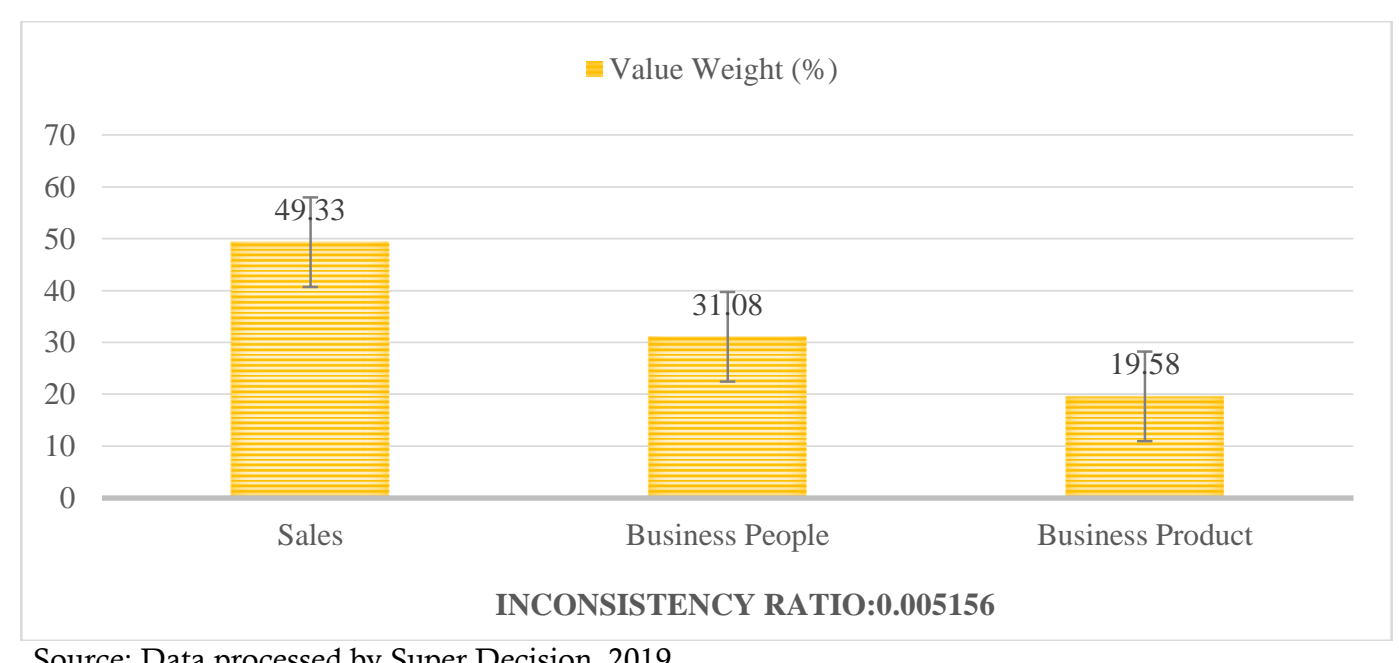

Source: Data processed by Super Decision, 2019.

Figure 5. ANP Output of Pairwise Comparative Matrices between Criteria

Figure 5 above shows that in the development strategy of the earthenware craft business groups in Kasongan which is seen from the priority value (eigen vector), where the selling aspect ranks first with a value weight of $49.33 \% \%$. Then, followed by aspect of business people with a value weight of $31.08 \%$, and aspect of business products with a value weight of $19.58 \%$. Furthermore, to determine the consistency of the respondents is 
by looking at the consistency index (CI). CI will be considered consistent if the value is less than $0.1(\mathrm{CI}<0.1)$. In Figure 5 above, the $\mathrm{CI}$ value is 0.005156 which means that the answers from the key person are consistent.

\section{Final Priority Determination}

The final priority in the Analytic Network Process (ANP) model is absolute weighting by using the interval scale (1.0) and as a measure of relative dominance. The priority value is obtained by normalizing the matrix vector. In the final priority, there are limiting weight, normalized by cluster and ranking. The final priority value can be seen in the following table. Final priority is the weight of all elements in which there are limiting and normalized by clusters. Limiting weight is the weight obtained from supermatrix limit while normalized by cluster is the division between the limiting weight of an element and the amount of limiting weight of an element in a component. The final priority determines the best alternative with the greatest final value. The final priority is obtained from the relationship between the criteria and the alternatives that have been described by the ANP model in Figure 6. The final priority for choosing the best strategy in developing the earthenware business group can be seen in the figure as follows:

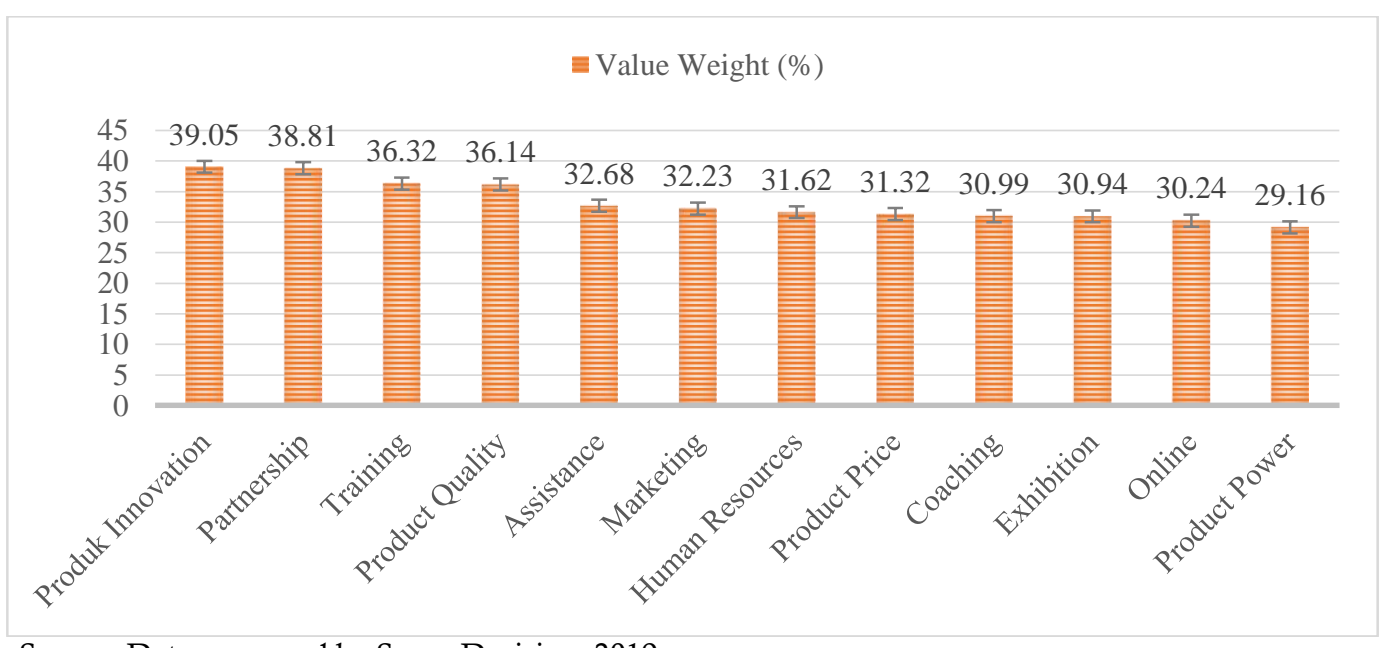

Source: Data processed by Super Decision, 2019.

Figure 6. ANP Output of Priority Determination for Development Strategy Outcomes of Business Group of the Earthenware Crafts in Kasongan.

Based on Figure 6, it can be known the priority of the development of the earthenware craft business group in Kasongan. Where the priority has been chosen above is a strategy has been determined by the key person in this case is a person who is an expert in his field that is processed through super decision software to obtain the best strategy in order to develop the earthenware craft business group in Kasongan. The result of the first priority is the aspect of product innovation with a priority value of $39.50 \%$. This indicates that in developing the business group of earthenware craft, the aspect of product innovation becomes an aspect that must be improved. The existence of product innovation will increase the selling value and attractiveness of the earthenware products produced so that it will be able to boost earthenware sales. 
The second priority is the partnership aspect with a value weight of $38.81 \%$. Partnership is one of the elements that should not be ignored in the development of a business. The existence of a business partnership will increase the strength of a business, especially in terms of capital and marketing. So far, there are not many earthenware craft business in Kasongan Village that have business partners, so they sometimes find it difficult to market their products, especially in large quantities. Business partnership can be done with the government, private sector, or other entrepreneurs.

The third priority is the training aspect with a value weight of $36.32 \%$. Training can be done to improve the expertise and skills of the Kasongan earthenware business actors. This training can be held by the government or other institutions such as from universities or from other institutions. The training provided can be in the form of good business management training, production training with technology, financial management training and marketing training globally. With the training that is participated by the Kasongan earthenware business actors, they will be able to develop the earthenware business they run.

\section{Alternative Cluster Priorities}

The determination of the priority of these alternative clusters will show the order of alternatives most prioritized in the development of the earthenware business group in Kasongan Village. The results of cluster priority determination from ANP analysis can be seen in the following figure:

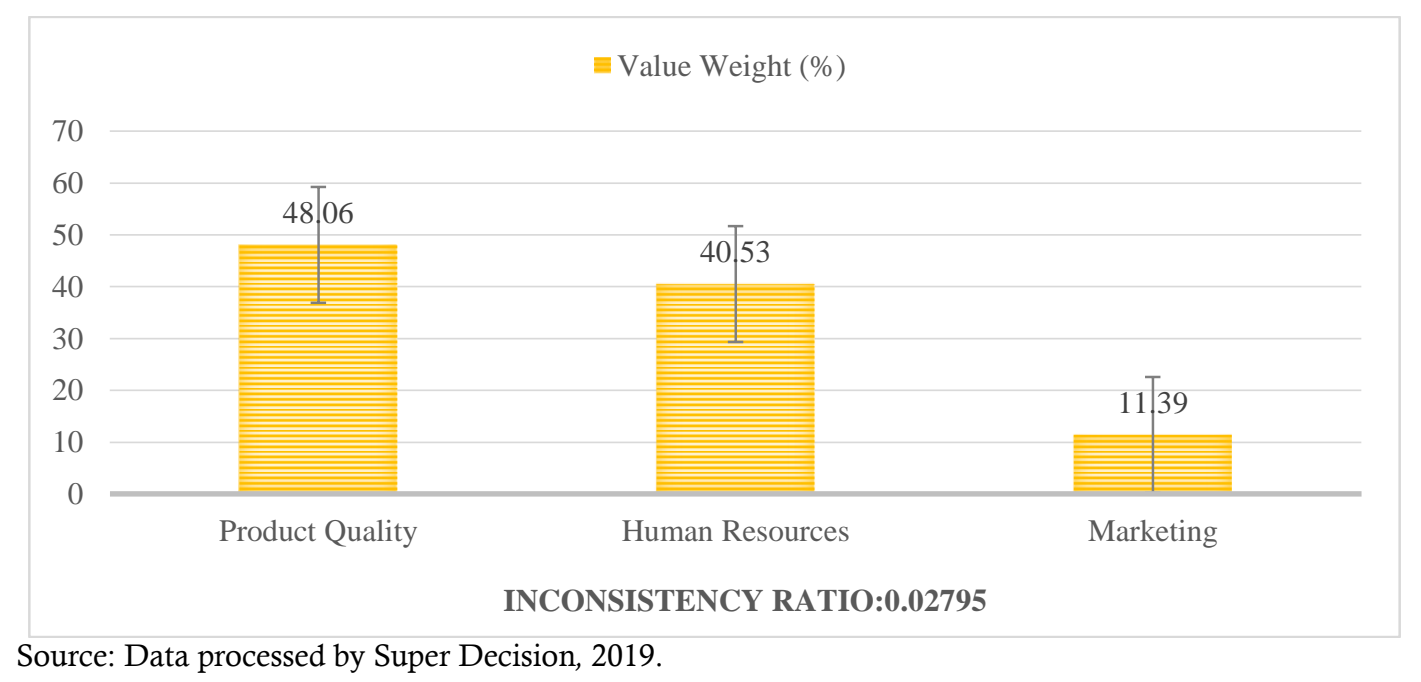

ource: Data processed by Super Decision, 2019.

Figure 7. ANP Output of the Determination of Alternative Cluster Priorities

Figure 7 above shows that the most prioritized alternative strategy in the development of earthenware craft business groups in Kasongan is product quality, with a value weight of $48.96 \%$. Then, the second priority is human resources with a value weight of $40.53 \%$ and the last order is marketing with a value weight of $11.39 \%$. The value of the inconsistency ratio in the aspect of product quality is $0.02795<0.1$, which means that the result of the analysis can be accepted. Product quality is the most prioritized strategic alternative in developing the earthenware business group in Kasongan Tourism Village. 
If a product has good quality, it will have a high selling value. Therefore, the Kasongan earthenware business actors must really pay attention to the quality of the product so that the business they run can grow better. With better product quality, it will be able to increase the selling price of the earthenware produced (Idrissi et. al, 2018). To maintain the quality of earthenware product which is good, then the earthenware raw materials must also be considered. The better the quality of the raw material for making earthenware, the better the quality of the earthenware will be, and conversely (Miyoshi et.al, 2014).

Furthermore, for the second order alternative strategy is human resources. Human resources are one of the important factors in a business. The higher the quality of existing human resources in a business, the business runs will be growing. Human resources owned by business people are still relatively low considering their low educational background. Even though there are only a few business people with high human resources. Even, high craftsmen' human resources on average are craftsmen who are not from Kasongan but are from other regions and now most of them have left their professions as earthenware craftsmen. The quality improvement of human resources of the earthenware artisans must continue to be improved so that this business will continue to be sustainable and growing.

As for the last order of alternative strategy is marketing. Marketing is the key to success of a business. Because the better the marketing strategy carried out it will directly affect the high sales of products produced. In order for earthenware products can be marketed properly, the craftsmen must get easy in accessing market information so that they can find out what kind of products consumers want in the market (Pelupessy, 2017). Most of the earthenware marketing in Kasongan still depends on customer orders. As a result, if there are no orders, they will not dare to produce earthenware in large quantities. This makes it difficult for earthenware production in Kasongan to develop. This condition can actually be anticipated by implementing marketing strategies that are oriented towards a wider market share, that is by participating in various events, online marketing, and export-oriented marketing training.

\section{CONCLUSIONS}

The earthenware craft business in Kasongan Tourism Village still experiences many problems. These problems must be addressed immediately so that this business can continue to grow. From the analysis results of the Analytic Network Process (ANP), it shows that in the development of the earthenware craftsmen business group in Kasongan Tourism Village, it must be done based on the priority order in each cluster / criteria, namely aspect of business actors, aspect of business products and aspect of sales. The first priority of these criteria is the aspect of sales with a value weight of $49.3 \% \%$, then followed by the aspect of business actor with a value weight of $31 \%$, and the aspect of business products with a value weight of $19.5 \%$. From the final result of the determination priority, it is obtained three main priorities namely aspect of product innovation with a weight of $39.16 \%$, partnership with a weight of $38.81 \%$, and training with a weight of 
$36.32 \%$. Meanwhile, the results of alternative clusters priority determination obtains the first alternative strategy sequence result is product quality with a weight of $48.06 \%$, then followed by human resources with a weight of $40.53 \%$ and the last is marketing with a weight of $11.39 \%$. With these results, it can be seen which aspects become priority to be improved in order to develop the earthenware crafts business group in Kasongan Tourism Village.

\section{REFERENCES}

Amirullah, Hardjanto. (2005). Pengantar Bisnis. Edisi Pertama. Yogyakarta: Graha Ilmu.

Boyd, Harper W. Dkk. (2000). Manajemen Pemasaran - Suatu Pendekatan Strategis Dengan Orientasi Global. Edisi Kedua.Jakarta: Erlangga.

Fatimah, Yuni Faridatul. (2012). Studi Industri Kerajinan Gerabah Kasongan di Desa Bangunjiwo Kecamatan Kasihan Kabupaten Bantul. Jurnal Seni dan Kewirausahaan, 7(1): 10-19.

Hanggana, Sri. (2006). Prinsip Dasar Akuntansi Biaya. Surakarta: Mediatama.

Hastuti, Indra. (2010). Perkembangan Usaha Industri Kerajinan Gerabah, Faktor yang Mempengaruhi dan Strategi Pemberdayaanya pada Masyarakat di Desa Melikan Kecamatan Wedi Kabupaten Klaten. Jurnal Ekonomi dan Bisnis, 3(1): 32-42.

Henden, E., Cataloglu, R., \& Aksuner, N. (2011). Determination of arsenic leaching from glazed and non-glazed Turkish traditional earthenware. Science of The Total Environment, 409(15):2993-2996.

Herdiansyah, Haris. (2010). Metodologi Penelitian Kuantitatif. Jakarta: Salemba Humanika.

Idrissi, Hicham E1 Boudour E1, Lahcen Daoudi, Meriam El Ouahabi, Frédéric Collin, \& Nathalie Fagel. (2018). The influence of clay composition and lithology on the industrial potential of earthenware. Construction and Building Materials. 172(1): 650659.

Irdayanti. (2012). Peran Pemerintah dalam Pengembangan UKM Berorientasi Ekspor Studi Kasus: Klaster Kasongan dalam Rantai Nilai Tambah Global,Jurnal Transnasional, 3(2): 56-67.

Khotimah, Tutik dan Rina Fiati. (2013). Peningkatan Keunggulan Kompetitif pada Umkm Gerabah Melalui Model E-Business. Jurnal Simetris, 3(1): 120-134.

Kotler, Philip. (2005). Manajemen Pemasaran. Edisi 11. Jakarta : Prenhalindo

Kuncoro, Mudrajad. (2007). Metode Kuantitatif, Teori dan Aplikasi Untuk Bisnis dan Ekonomi. Yogyakarta: UPP STIM YKPN.

Miyoshi, Y., Nagano, M., Ishigo, S., Ito, Y., Hashiguchi, K., Hishida, N., Hamase, K. (2014). Chiral amino acid analysis of Japanese traditional Kurozu and the developmental changes during earthenware jar fermentation processes. Journal of Chromatography, B (966):187-192.

Mujahidin, Akhmad. (2007). Ekonomi Islam, Jakarta: PT.RajaGrafindo Persada.

Niziolek, L. C. (2013). Earthenware production and distribution in the prehispanic Philippine polity of Tanjay: results from laser ablation-inductively coupled plasma-mass spectrometry (LAICP-MS). Journal of Archaeological Science, 40(6): 2824-2839. 
Nugraha, Ardi Listyawan. (2011). Pengaruh Modal Usaha. Yogyakarta: Pustaka Pelajar.

Pelupessy, Merry Margareth. (2017). Analisis Kinerja Pemasaran Pada Industri Olahan Gerabah di Kabupaten Takalar Provinsi Sulawesi Selatan. Jurnal Manis,1(1): 24-36.

Rusydiana, A.M. dan Devi Abrista.(2013).Analytic Network Process: Pengantar Teoridan Aplikasi. Bogor: Smart Publisher.

Sofa, Innes Maeya. (2011). Pemberdayaan Ekonomi Pengrajin Gerabah: Study Kasus Pengrajin Gerabah Kasongan di Desa Bangunjiwo Kabupaten Bantul. Jurnal Ekonomika, Vol 3(1): 46-53.

Sugiyono. (2017). Metode Peneitian Kuantitatif, Kualitatif dan R\&D. Bandung: Alfabeta.

Syamsudin, Lukman. (2001). Manajemen Keuangan Perusahaan (Konsep AplikasiDalam Perencanaan, Pengawasamn, dan Pengambilan Keputusan). Jakarta: PT.Raja Grafindo Persada.

Ueda, K., Miksic, J. N., Wibisono, S. C., Harkantiningsih, N., Goh, G. Y., Edwards McKinnon, E., \& Shah, A. M. Z. (2017). Trade and consumption of fine paste ware in Southeast Asia: Petrographic and portable X-ray fluorescence analyses of ninth- to fourteenth-century earthenware. Archaeological Research in Asia, 11(3): 58-68. 